\title{
Pengaruh Modal, Lokasi, dan Jam Berdagang Terhadap Pendapatan Pedagang Pasar Jurnal Ecces
}

\author{
Sitti Aisyah ${ }^{1}$ \\ Muh. Zulfi Qadri ${ }^{2}$ \\ 1,2, Program Studi Ilmu Ekonomi \\ Fakultas Ekonomi dan Bisnis Islam Universitas Islam Negeri Alauddin Makassar \\ Jl. Yasin Limpo, No. 36 Samata, Gowa, Sulawesi Selatan \\ E-mail :sitti.aisyah.s@uin-alauddin.ac.id ${ }^{1}$, zulfi.qadri@gmail.com²
}

\section{Abstrak: Pengaruh Modal, Jam Berdagang, dan Lokasi Terhadap Penghidupan Pedagang Pasar}

Pendapatan pedagang pasca relokasi di pasar sentral palakka, Kabupaten Bone semakin tidak menentu dari waktu ke waktu. Bahkan, struktur pendapatan pedagang setempat semakin memburuk, yang ditandai dengan rendahnya tingkat pendapatan para pedagang tersebut. Penelitian ini bertujuan Untuk mengetahui: 1) apakah modal berpengruh terhadap pendapatan pedagang Pasar Sentral Palakka Kecamatan Tanete Riattang Barat Kabupaten Bone. 2) apakah jam berdagang berpengaruh terhadap pendapatan pedagang Pasar Sentral Palakka Kecamatan Tanete Riattang Barat Kabupaten Bone. 3) apakah lokasi usaha berpengaruh terhadap pendapatan pedagang Pasar Sentral Palakka Kecamatan Tanete Riattang Barat Kabupaten Bone. Jumlah populasi dalam penelitian ini yaitu sebanyak 450 orang, dengan penarikan sampel menggunakan rumus slovin menjadi 81 responden. Hasil penelitian menunjukan bahwa : (1) terdapat pengaruh positif modal terhadap pendapatan Pedagang Pasar Sentral Palakka Kabupaten Bone; (2) terdapat pengaruh positif jam berdagang terhadap pendapatan Pedagang Pasar Sentral Palakka Kabupaten Bone; (3) terdapat pengaruh positif lokasi terhadap pendapatan Pedagang Pasar Sentral Palakka Kabupaten Bone. Koefisien determinasi R2 sebesar 0,784 dapat diartikan bahwa sebesar 78,4\% variabel pendapatan Pedagang Pasar Sentral Palakka Kabupaten Bone dipengaruhi oleh variabel Modal (X1), Jam Berdagang (X2), Dan Lokasi(X3). Sedangkan yang sebesar $21,6 \%$ dipengaruhi oleh variabel lain di luar penelitian.

Kata Kunci: Modal, Jam Berdagang dan Lokasi. 


\section{Abstract: Capital Influence, Trading Hours, and Location to Market Trader Livelihoods}

Post-relocation merchant income in the Palakka Central Market, Bone Regency is increasingly erratic from time to time. In fact, the structure of income of local traders is getting worse, which is marked by the low level of income of these traders. This study aims to find out: 1) whether the capital affects the income of traders in Palakka Central Market, Tanete Riattang Barat District, Bone Regency. 2) whether the trading hours affect the income of traders in Palakka Central Market, Tanete Riattang Barat District, Bone Regency. 3) whether the business location influences the income of traders in Palakka Central Market, Tanete Riattang Barat District, Bone Regency. The population in this study is 450 people, with sampling using the Slovin formula to 81 respondents. The results of the study show that: (1) there is a positive effect of capital on the income of Palakka Central Market Traders in Bone Regency; (2) there is a positive influence on the hours of trading on the income of Palakka Central Market Traders in Bone Regency; (3) there is a positive effect of location on the income of Palakka Central Market Traders in Bone Regency. The coefficient of determination R2 is 0.784 can be interpreted that $78.4 \%$ of the income variable Palakka Central Market Traders Bone Regency is influenced by the variable Capital (X1), Trading Hours (X2), and Location (X3). Whereas $21.6 \%$ is influenced by other variables outside the research.

Keywords: Capital, Trading Hours and Location.

\section{PENDAHULUAN / INTRODUCTION}

Pendapatan pedagang pasca relokasi di pasar sentral palakka, Kabupaten Bone semakin tidak menentu dari waktu ke waktu. Bahkan, struktur pendapatan pedagang setempat semakin memburuk, yang ditandai dengan rendahnya tingkat pendapatan para pedagang tersebut. Faktor modal, merupakan faktor yang mempengaruhi pendapatan pedagang, selain itu juga diakibatkan oleh jam berdagang. Jam berdagang, merupakan waktu yang di butuhkan oleh seseorang dalam melakukan pekerjaan dalam tempo waktu satu hari. Jam berdagang sangat berpengaruh terhadap tingkat pendapatan. Dalam praktiknya semakin lama jam berdagang, maka semakin tinggi pula kesempatan untuk memperoleh pendapatan yang jauh lebih baik. Pada saat peneliti, mengadakan observasi dan wawancara di Pasar Sentral Palakka Kabupaten Bone, pedagang mulai berjualan pukul 05.00, bahkan ada yang lebih pagi bagi pedagang sembako. Banyak pedagang yang mengeluh dengan terjadinya penurunan pendapatan. Salah satu pedagang mengatakan bahwa rata-rata pendapatan di pasar sentral palakka hanya sebesar Rp.200.000,00Rp.300.000,00/hari, di bandingkan dengan lokasi pasar sentral lama, yag mampu meraup 
Aisyah, Qadri, Pengaruh Modal, Lokasi, dan Jam Berdagang ...

pendapatan rata-rata Rp.500.000,00/hari. Pada prinsipnya, keadaan pasar sentral palakka cukup baik. Tempat-tempat berjualan para pedagang, seperti los dan kios telah tertata cukup baik. Namun, masih terdapat banyak kekurangan, seperti banyak pedagang yang menempati lokasi usaha strategis dan ada pula para pedagang yang menempati lokasi usaha kurang strategis, yang letaknya jauh dari keramaian, dampaknya distribusi pendapatan juga kian tidak distributif.

Setiap individu yang ada dalam masyarakat me-miliki sejumlah kebutuhan namun setiap individu tidak dapat memenuhi semua kebutuhan yang ada maka dari itu mereka melakukan interaksi sosial (hubungan sosial). Interaksi sosial yang dilakukan antar individu maupun antar kelompok membentuk sejumlah pranta sosial salah satunya pranta ekonomi. Salah satu pranata ekonomi adalah pasar. Pasar dalam pengertian sempit adalah tempat berkumpul dan bertemunya penjual dan pembeli pada suatu lokasi tertentu. Pasar pengertian luas adalah, mekanisme bertemunya kepentingan pro-dusen dan konsumen sebagai sumber informasi bagi pelaku ekonomi serta juga merupakan sarana dalam meningkatkan kepuasan konsumen maupun produsen. Aktivitas ekonomi pasar adalah merupakan tempat dimana proses transaksi antara pembeli dan penjual berlangsung, serta sebagai tempat untuk mendapatkan alat pemuas kebutuhan dengan harga yang sesuai.

Dalam perekonomian suatu negara maupun daerah, kenyataannya terdapat berbagai sektor-sektor yang memperlihatkan tingkat pertumbuhan perekonomian yaitu sektor formal dan sektor informal. Dalam sektor informal, umumnya terdapat usaha kecil dengan modal, ruang lingkup, dan pengembangan yang terbatas serta sedikit sekali menerima proteksi secara resmi dari pemerintah. Banyak sektor informal yang mampu diangkat sebagai suatu kegiatan atau pekerjaan untuk meng-hasilkan pendapatan pada suatu masyarakat. Usaha berdagang merupakan salah satu usaha yang menghasilkan penghasilan bagi masyarakat, dalam hal ini adalah usaha berdagang dalam suatu pasar tradisional. Pasar tradisional merupakan tempat berinteraksi sosial antara pedagang dan pembeli. Proses jual beli, biasanya dengan harga yang diberikan untuk suatu barang bukan merupakan harga tetap, dalam arti lain masih dapat ditawar. Bangunan biasanya terdiri dari kios-kios, los dan dasaran terbuka yang dibuka oleh penjual maupun pengelola pasar. Kebanyakan pedagang menjual bahan-bahan pokok serta keperluan rumah tangga, seperti bahan-bahan makanan berupa ikan, buah , sayur-sayuran, telur, daging, pakaian, barang elektronik, jasa dan lain- 
lain. Selain lokasi pasar tradisional dapat berada di tempat yang terbuka atau bahkan di pinggir jalan.

Setelah usaha dimulai, yang diperlukan suatu usaha agar dapat berjalan dengan lancar dan berkembang adalah pengelolaan yang baik. Salah satu faktor yang sangat penting dalam mengelola usaha adalah modal, menurut swastha salah satu faktor yang bisa mempengaruhi pendapatan para pedagang pasar yaitu modal. Modal usaha yang relatif besar jumlahnya akan memungkinkan suatu unit penjualan dengan banyak jenis produk. Dengan cara tersebut, pendapatan yang di dapatnya juga semakin besar.

\section{TINJAUAN TEORITIK / LITERATURE REVIEW}

Todaro (2003) mengungkapkan bahwa salah satu faktor produksi yang tidak kalah pentingnya adalah modal, sebab didalam suatu usaha masalah modal mempunyai hubungan yang sangat kuat dengan berhasil tidaknya suatu usaha yang telah didirikan. Modal adalah semua bentuk kekayaan yang dapat digunakan langsung maupun tidak langsung dalam proses produksi untuk menambah output. Dalam pengertian ekonomi, modal yaitu barang atau uang yang bersama-sama faktor-faktor produksi tanah dan tenaga kerja menghasilkan barang-barang dan jasa-jasa baru. Modal atau biaya adalah salah satu faktor yang sangat penting bagi setiap usaha, baik skala kecil, menengah maupun besar.

Modal merupakan input (faktor produksi) yang sangat penting dalam menentukan tinggi rendahnya pendapatan. Peran penting modal dalam meningkatkan output dijelaskan juga dalam teori Adam Smith, yang menyatakan bahwa modal merupakan unsur produksi yang secara aktif akan menentukan tingkat output. Jumlah output yang dihasilkan sangat ditentukan oleh berapa besar modal yang digunakan. Dan pengunaan modal juga dijelaskan dalam teorinya Harrod- Domar, fungsi produksi yaitu sejumlah modal hanya dapat menciptakan suatu tingkat output tertentu dalam suatu kegiatan produksi. Jadi, setiap kegiatan ekonomi akan dapat menyisihkan pendapatan yang akan digunakan oleh memenuhi kebutuhan hidup. Tetapi bukan berarti merupakan faktor satu-satunya yang dapat meningkatkan pendapatan. Sehigga dalam hal ini modal bagi pedagang juga merupakan salah satu faktor produksi yang mempengaruhi tingkat pendapatan pedagang pasar sentral palakka. Didalam suatu usaha masalah modal mempunyai hubungan yang 
Aisyah, Qadri, Pengaruh Modal, Lokasi, dan Jam Berdagang ...

sangat kuat dengan berhasil tidaknya suatu usaha yang telah didirikan. Modal dapat diklasifikasi menjadi dua bagian. (1). Modal tetap yakni modal yang memberikan jasa untuk proes produksi dalam jangka waktu yang relative lama dan tidak terpengaruh oleh besar kecilnya jumlah produksi. (2) Modal lancer adalah memberikan jasa hanya sekali dalam proses produksi, bisa dalam bentuk bahan-bahan baku dan kebutuhan lain sebagai penunjang usaha.

Namun, sangat berbeda dengan pandangan Schultz pada tahun 1960 dalam Ancok, (2002) dan Fattah (2004), Ross dkk., (1997) yang berjudul investment in Human Capital di hadapan para ahli ekonomi dan pejabat yang tergabung dalam American Economic Assosiation merupakan peletak dasar teori atau konsep modal manusia (human capital concept). Konsep ini pada intinya menganggap bahwa manusia merupakan suatu bentuk modal atau capital, yang sebelumnya berbeda dengan tafsiran bentuk-bentuk kapital lainnya, seperti mesin, teknologi, tanah, uang, dan material atau yang biasa disebut sebagai physical capital. Manusia sebagai dipandang sebagai human capital tercermin dalam bentuk pengetahuan, gagasan (ide), kreativitas, keterampilan, dan produktivitas kerja. Tidak seperti bentukkapital lain yang hanya diperlakukan sebagai tools, human capital ini dapat menginvestasikan dirinya sendiri melalui berbagai bentuk investasi SDM, diantaranya pendidikan formal, pendidikan informal, pengalaman kerja, kesehatan, dan gizi serta transmigrasi.

Modal manusia adalah komponen yang sangat penting di dalam organisasi. Manusia dengan segala kemampuannya bila dikerahkan keseluruhannya akan menghasilkan kinerja yang luar biasa. Ada enam komponen dari modal manusia, yakni: (1) Modal intelektual; (2) Modal emosional; (3) Modal sosial; (4) Modal ketabahan, (5) Modal moral; dan (6) Modal kesehatan. Keenam komponen modal manusia ini akan muncul dalam sebuah kinerja yang optimum apabila disertai oleh modal kepemimpinan dan modal struktur organisasi yang memberikan wahana kerja yang mendukung. Human capital juga disebut sebagai modal intelektual. Modal intelektual adalah perangkat yang diperlukan untuk menemukaan peluang dan mengelola ancaman dalam kehidupan. Banyak pakar yang mengatakan bahwa modal intelektual sangat besar peranannya di dalam menambah nilai suatu kegiatan. Organisasi yang unggul dan meraih banyak keuntungan adalah organisasi yang terus menerus mengembangkan sumberdaya manusianya. Manusia memiliki sifat proaktif dan inovatif untuk mengelola perubahan lingkungan kehidupan (ekonomi, sosial, politik, teknologi, hukum dan lain-lain) yang sangat tinggi kecepatannya. Mereka yang tidak beradaptasi pada perubahan yang super cepat ini akan dilanda kesulitan. 
Fitz-Enz (2000) mendeskripsikan human capital sebagai kombinasi dari tiga faktor, yaitu: 1) karakter atau sifat yang dibawa ke pekerjaan, misalnya intelegensi, energi, sikap positif, keandalan, dan komitmen, 2) kemampuan seseorang untuk belajar, yaitu kecerdasan, imajinasi, kreatifitas dan bakat dan 3) motivasi untuk berbagi informasi dan pengetahuan, yaitu semangat tim dan orientasi tujuan. Davemport (1999) mendeskripsikan human capital terdiri atas empat hal: kemampuan, perilaku, usaha, dan waktu, yang semua ini dimiliki dan dikendalikan sendiri oleh karyawan. Chen dan Lin (2003) menyatakan bahwa pengeluaran perusahaan yang berhububungan dengan sumber daya manusia harus dipandang sebagai investasi dalam human capital. Misalnya program training yang bertujuan untuk menambah value karyawan di masa depan harus dianggap sebagai investasi. Menurut Wealtherly (2003), Nilai perusahaan didasarkan atas tiga kelompok utama aset, yaitu:

1. Financial asset, misalnya kas surat-surat berharga yang sering disebut juga dengan financial capital.

2. Physical asset, terdiri atas peralatan, gedung, tanah, disebut juga dengan tangible asset.

3. Intangible asset, misalnya organizational capital, seperti aliansi bisnis, customer capital, merek, reputasi kualitas dan pelayanan; dan intellectual capital (paten, desain produk, dan teknologi), goodwill, dan human capital.

\section{METODE PENELITIAN / METHODS}

Metode penelitian yang digunakan dalam penelitian ini adalah metode deskriptif kuantitatif. Penelitian ini menggunakan metode regresi linear berganda. Data yang digunakan adalah data sekunder yaitu data PDRB sektoral Kabupaten Bone dan PDRB sektor perdagangan di Kabupaten Bone yang diperoleh dari Badan Pusat Statistik Kabupaten Bone. Selain itu, data yang digunakan adalah data primer. Populasi yang ada di objek penelitian ini adalah semua pedagang pasar sentral palakka yang tercakup dalam kriteria tersebut sebanyak 450. Penelitian ini, menggunakan penentuan sampel menggunakan rumus Slovin dan menghasilkan 81 responden. Data diperoleh melalui jawaban kuisioner yang diperoleh dari para pedagang yang menjadi objek penelitian beserta hasil wawancara dengan pihak- 
pihak terkait. Lokasi yang menjadi tempat penelitian adalah Pasar Sentral Palakka, Kecamatan Tanete Riattang Barat Kabupaten Bone Sulawesi Selatan. Metode analisis yang digunakan untuk menguji hipotesis adalah regresi linear berganda dengan alat analisis output SPSS 16 sebagai berikut:

$Y=a+\beta 1 X 1+\beta 2 X 2+\beta 3 X 3+e$

Keterangan :

$=$ pendapatan pedagang

$\mathrm{a} \quad=$ Konstanta

$\mathrm{X} 1=$ modal

X2 $=$ jam berdagang

X3 = lokasi usaha

$\beta 1-\beta 2-\beta 32=$ Koefisien regresi berganda

e $\quad=$ error term

\section{HASIL DAN PEMBAHASAN / DISCUSSION}

Pasar Sentral Palakka adalah pasar sentral di Kabupaten Bone yang dahulunya berada di pusat Kota Watampone, namun mengalami perpindahan ke daerah palakka karena terjadinya kebakaran serta penertiban wilayah kota. Pasar palakka memiliki luas sebesar 12 ha. Keadaan pasar yang cukup luas membuat pasar ini sangat jelas jika sepi pembeli. Pasar seni merupakan pusat perdagangan dan memungkinkan distribusi dan alokasi sumber daya dalam masyrakat dan mengizinkan semua item yang diperdagangkan dengan harga yang telah dibatasi oleh Dinas Pendapatan Daerah Kabupaten Bone. Untuk melakukan aktifitas jual beli pasar ini dilengkapi sarana pasar seperti ruko, toko, kios, lods serta tempat parkir khusus yang menjadi sumber pendapatan retribusi pasar. Bangunan seperti ruko dan toko dijadikan sebagai tempat berdagang sekaligus tempat tinggal bagi sebagian pedagang di pasar. 


\section{Analisis Regresi Linear Berganda}

Persamaan regresi dapat dilihat dari tabel hasil uji coefisient berdasarkan output SPSS versi 16 terhadap ke 4 variabel modal, jam berdagang, dan lokasi, terhadap pendapatan pedagang ditunjukkan pada tabel 1 berikut:

Tabel 1

Hasil Regresi Berganda Coefficients $^{\mathrm{a}}$

\begin{tabular}{cccccc}
\hline \multirow{2}{*}{ Model } & \multicolumn{2}{c}{ Unstandardized Coefficients } & $\begin{array}{c}\text { Standardized } \\
\text { Coefficients }\end{array}$ & $\mathrm{T}$ & Sig. \\
& $\mathrm{B}$ & Std. Error & Beta & & \\
\cline { 2 - 5 } & -4.403 & 1.854 & & -2.375 & .020 \\
\hline (Constant) & .733 & .055 & .736 & 3.360 & .000 \\
\hline Modal & 523266.071 & 1498388.470 & .209 & 3.492 & .001 \\
\hline Jam Berdagang & 283397.177 & 949211.127 & .171 & 2.986 & .004 \\
\hline Lokasi & & & & & \\
\hline
\end{tabular}

Sumber : Output SPSS 16 data diolah, Tahun 2018

Berdasarkan tabel 1 dapat dilihat hasil koefisien regresi $(\beta)$ di atas, I maka diperoleh persamaan regresi sebagai berikut :

$$
\begin{aligned}
& Y=\beta_{0}+\beta_{1} X_{1}+\beta_{2} X_{2}+\beta_{3} X_{3}+\mu \\
& Y=-4.403+0.733 X_{1}+523266.071 X_{2}+283397.177 X_{3}+\mu
\end{aligned}
$$

Hasil dari persamaan regresi di atas dapat diinterpretasikan sebagai berikut:

1) Nilai koefisien $\beta_{0}$ sebesar -4.403 jika variabel modal $\left(X_{1}\right)$, jam berdagang $\left(X_{2}\right)$, dan lokasi $\left(\mathrm{X}_{3}\right)$, konstan atau $\mathrm{X}=0$, maka variabel pendapatan $(\mathrm{Y})$ tidak mengalami perubahan atau konstan

2) Nilai koefisien $\beta_{1}=0.733$. Artinya jika variabel jam berdagang, dan lokasi konstan. Dan variabel modal mengalami kenaikan sebesar 1\% maka pendapatan pedagang mengalami peningkatan sebesar 0.733 . Koefisien bernilai positif artinya terjadi hubungan positif antara modal dan pendapatan pedagang karena semakin naik modal kerja maka pendapatan semakin meningkat.

3) Nilai koefisien $\beta_{2}=523266.071$. Artinya jika variabel modal dan lokasi konstan. Dan variabel jam berdagang mengalami kenaikan sebesar $1 \%$ maka pendapatan pedagang mengalami peningkatan sebesar 523266.071 . Koefisien bernilai positif 
artinya terjadi hubungan positif antara Jam berdagang dan pendapatan karena semakin lama berdagang maka pendapatan semakin meningkat.

4) Nilai koefisien $\beta_{3}=283397.177$. Artinya jika variabel modal dan jam berdagang konstan. Dan variabel lokasi mengalami kenaikan sebesar $1 \%$ maka pendapatan pedagang mengalami peningkatan sebesar 283397.177. Koefisien bernilai positif artinya terjadi hubungan positif antara lokasi dan pendapatan karena dengan lokasi yang strategis maka pendapatan semakin meningkat.

\section{Uji Hipotesis}

Uji hipotesis merupakan jawaban sementara dari rumusan masalah dalam penelitian. Uji hipotesis terbagi menjadi tiga yaitu:

\section{Uji Simultan (Uji F)}

Uji F merupakan uji secara simultan untuk mengetahui apakah variabel modal, jam berdagang, dan lokasi secara simultan mempunyai pengaruh yang signifikan terhadap pendapatan pedagang pasar Sentral Palakka Kecamatan Tanete Riattang Timur Kabupaten Bone.

Dari hasil analisis dapat dilihat pada tabel 2 berikut:

Tabel 2

Hasil Uji Simultan (Uji F)

\begin{tabular}{ccccccc}
\multicolumn{8}{c}{ MNOVA $^{\mathrm{a}}$} \\
\hline \multirow{2}{*}{ Model } & $\begin{array}{c}\text { Sum of } \\
\text { Squares }\end{array}$ & Df & Mean Square & $F$ & Sig. \\
\hline \multirow{3}{*}{1} & Regression & 1.031 & 3 & 3.436 & 98.022 & $.000^{\mathrm{a}}$ \\
\cline { 2 - 7 } & Residual & 2.699 & 77 & 3.506 & & \\
\cline { 2 - 7 } & Total & 1.301 & 80 & & & \\
\cline { 2 - 7 }
\end{tabular}

Sumber : Output SPSS 16 data diolah, Tahun 2018.

Dari hasil regresi yang ditunjukkan pada tabel $2 \mathrm{~F}$ hitung sebesar 98.022 dengan tingkat probalitas 0,000 (signifikansi). Pengaruh variabel modal $\left(X_{1}\right)$, Jam Berdagang $\left(X_{2}\right)$, dan lokasi $\left(\mathrm{X}_{3}\right)$, terhadap pendapatan pedagang $(\mathrm{Y})$, maka diperoleh nilai signifikan $.000<$ 0.05. Hal ini menunjukkan bahwa ketiga variabel bebas secara simultan berpengaruh signifikan terhadap variabel dependen. 


\section{Uji Parsial (Uji t)}

Uji t dilakukan untuk mengetahui pengaruh secara parsial variabel independen (modal, jam berdagang, dan lokasi) terhadap variabel dependen (pendapatan pedagang). Dari hasil analisis dapat dilihat pada tabel 2 berikut:

Tabel 3

Hasil Uji Parsial (Uji t) Coefficients $^{a}$

\begin{tabular}{|c|c|c|c|c|c|c|}
\hline & \multirow[t]{2}{*}{ Model } & \multicolumn{2}{|c|}{ Unstandardized Coefficients } & \multirow{2}{*}{$\begin{array}{c}\text { Standardized } \\
\text { Coefficients }\end{array}$} & \multirow[t]{2}{*}{$\mathrm{T}$} & \multirow[t]{2}{*}{ Sig. } \\
\hline & & $B$ & Std. Error & & & \\
\hline \multirow{4}{*}{1} & (Constant) & -4.403 & 1.854 & & -2.375 & .020 \\
\hline & Modal & .733 & .055 & .736 & 13.360 & .000 \\
\hline & Jam Berdagang & 523266.071 & 1498388.470 & .209 & 3.492 & .001 \\
\hline & Lokasi & 283397.177 & 949211.127 & .171 & 2.986 & .004 \\
\hline
\end{tabular}

Sumber : Output SPSS 16 data diolah, Tahun 2018

Tabel 3 pengaruh secara parsial variabel modal dan lokasi, terhadap pendapatan pedagang dapat dilihat dari tingkat signifikansi. Variabel modal, jam berdagang dan lokasii memiliki tingkat signifikan $<0.05$, maka semua variabel independen berhubungan positif terhadap variabel dependen.

Hasil pengujian hipotesis variabel independen secara parsial terhadap variabel dependennya dapat dianalisis sebagai berikut:

\section{a. Pengaruh Modal Terhadap Pendapatan Pedagang Pasar Sentral Palakka Kabupaten Bone}

Berdasarkan hasil uji t diperoleh keterangan bahwa variabel modal berhubungan positif dan signifikan terhadap pendapatan pedagang. Variabel modal $\left(\mathrm{X}_{1}\right)$ menunjukkan nilai signifikan $<(0.000<0.05)$ dengan nilai $\beta_{1}$ sebesar 0.733 , Ini berarti semakin banyak modal yang digunakan maka semakin bertambah tingkat pendapatan Pedagang.

\section{b. Pengaruh Jam Berdagang Terhadap Pendapatan Pedagang Pasar Sentral Palakka Kabupaten Bone}

Berdasarkan hasil uji t diperoleh keterangan bahwa variabel Jam berdagang berhubungan positif dan tidak signifikan terhadap pendapatan pedagang variabel Jam 
Aisyah, Qadri, Pengaruh Modal, Lokasi, dan Jam Berdagang ...

berdagang $\left(X_{2}\right)$ menunjukkan nilai signifikan $(0.001<0.05)$ dengan nilai $\beta_{2}$ sebesar 523266.071, Ini berarti semakin lama waktu berdagang maka semakin bertambah tingkat pendapatan pedagang.

\section{Pengaruh Lokasi Terhadap Pendapatan Pedagang Pasar Sentral Palakka Kabupaten Bone}

Berdasarkan hasil uji $\mathrm{t}$ diperoleh keterangan bahwa variabel lokasi berhubungan positif dan signifikan terhadap pendapatan pedagang variabel lokasi $\left(X_{3}\right)$ menunjukkan nilai signifikan < $(0.004<0.05)$ dengan nilai $\beta_{3}$ sebesar 283397.177, Ini berarti semakin strategis lokasi yang digunakan maka semakin bertambah tingkat pendapatan pedagang.

\section{Koefesien Determinasi $\left(\mathbf{R}^{2}\right)$}

Uji koefisien determinasi ini digunakan untuk mengukur seberapa jauh variabelvariabel bebas dalam menerangkan variabel terikatnya. Nilai koefisien determinasi untuk 3 variabel bebas ditentukan dengan nilai adjusted $\mathrm{R}$ square, Adapun hasil koefisien determinasi dapat dilihat pada tabel 4 berikut

Tabel 4

Koefisien Determinasi $\left(\mathrm{R}^{2}\right)$

Model Summary ${ }^{\mathrm{b}}$

\begin{tabular}{cccccc}
\hline Model & R & R Square & $\begin{array}{c}\text { Adjusted R } \\
\text { Square }\end{array}$ & $\begin{array}{c}\text { Std. Error of } \\
\text { the Estimate }\end{array}$ & Durbin-Watson \\
\hline 1 & $.890_{\mathrm{a}}$ & .792 & 784 & 6.378 & 1.726 \\
\hline
\end{tabular}

Sumber : Output SPSS 24 data diolah, Tahun 2018.

Tabel tersebut menunjukkan bahwa hasil dari perhitungan diperoleh nilai koefisien determinasi yang disimbolkan dengan $\mathrm{R}^{2}$ sebesar 0.792 , dengan kata lain hal ini menunjukkan bahwa besar persentase variasi pendapatan pedagang yang bisa dijelaskan oleh variasi dari ketiga variabel bebas yaitu modal kerja $\left(X_{1}\right)$, jam berdagang $\left(X_{2}\right)$, dan lokasi $\left(X_{3}\right)$ sebesar 79,2\% sedangkan sisanya sebesar $20.8 \%$ dijelaskan oleh variabel-variabel lain diluar penelitian, contohnya variabel pengalaman, jenis dagangan, dan lain-lain.

\section{Uji F (Simultan)}

Berdasarkan hasil uji simultan maka di ketahui jumlah untuk nilai variabel modal, jam berdagang, dan lokasi terhadap pendapatan pedagang dengan nila signifikan 0,000<0,05 
hasil ini menujukan bahwa secara simultan berpengaruh terhadap tingkat pendapatan pedagang.

Pendapatan sangat berpengaruh bagi kelangsungan hidup pedagang, semakin besar pendapatan yang diperoleh maka semakin besar kemampuan pedagang untuk membiayai segala pengeluaran dan kegiatan-kegiatan yang akan dilakukan oleh pedagang. ${ }^{1} \mathrm{Hal}$ ini berarti ketika pedagang memmpunyai modal yang banyak akan mempengaruhi pendapatan karena modal, pedagang akan menambah barang dagangan dan peralatan dagangan yang akan diminati oleh konsumen. bahkan pedagang akan menambah jam berdagang.

Lokasi juga sangat memegang peranan penting dalam percepatan pertumbuhan ekonomi suatu daerah, demikian juga dengan lokasi pasar sebagai pusat pembelanjaan bagi masyarakat. Dengan demikian teori lokasi merupakan teori dasar dalam analisis spasial dimana tata ruang dan lokasi kegiatan ekonomi merupakan unsur utama. Teori lokasi ini memberikan kerangka analisis yang baik dan sistematis mengenai pemilihan lokasi kegiatan ekonomi (dalam hal ini adalah lokasi pasar tradisional sebagai pusat pembelanjaan).

\section{Pembahasan Uji T (Parsial)}

\section{a. Pengaruh Modal Terhadap Pendapatan Pedagang Pasar Sentral Palakka di Kabupaten Bone}

Dari Hasil uji persial diketahui bahwa modal, $(0,000<0,05)$, berhubungan positif terhadap pendapatan pedagang. Sehingga, untuk mendapatkan penambahan pendapatan yang besar harus diikuti dengan penambahan modal, jam berdagang dan lokasi yang strategis agar pendapatan pedagang juga bertambah.

Hal ini sangat sesuai dengan apa yang terjadi pada pedagang yang berada dipasar sentral palakka, karena pada dasarnya dengan penambahan modal maka akan berpengaruh pada biaya operasional yang dikeluarkan dalam kegiatan berdagang dan dengan jumlah modal yang meningkat sehingga dana yang digunakan untuk membeli input akan meningkat. Modal yang digunakan oleh pedagang di Pasar Sentral Palakka Kabupaten Bone yaitu modal yang bersumber dari dua pihak yaitu modal dari juragan dan modal sendiri, modal dari juragan yaitu modal yang diberikan oleh pemilik modal atau juragan dan pedagang yang menggunakan modal dari juragan maka akan melakukan pembagian hasil. 
Aisyah, Qadri, Pengaruh Modal, Lokasi, dan Jam Berdagang ...

Pengaruh positif dan signifikan modal terhadap pendapatan pedagang Pasar Sentral Palakka di Kabupaten Bone sesuai dengan kajian teoritis dalam penelitian ini yaitu swasta (2002) menyatakan bahwa faktor yang mempengaruhi pendapatan pedagang diantaranya ada kondisi dan kemampuan pedagang , kondisi pasar, modal, kondisi organisasi dan faktor lain yang mampu mempengaruhi pendapatan pedagang.

Modal yaitu semua bentuk kekayaan yang dapat digunakan langsung maupun tidak langsung dalam proses produksi untuk menambah output yang akan dihasilkan². Peran penting modal dalam meningkatkan output dijelaskan juga dalam teori Adam Smith, yang menyatakan bahwa modal merupakan unsur produksi yang secara aktif akan menentukan tingkat output. Jumlah output yang dihasilkan sangat ditentukan oleh berapa besar modal yang digunakan, Paul Michael Todaro (2003). Dan pengunaan modal juga dijelaskan dalam teorinya Harrod- Domar, fungsi produksi yaitu sejumlah modal hanya dapat menciptakan suatu tingkat output tertentu dalam suatu kegiatan produksi. Jadi, setiap kegiatan ekonomi akan dapat menyisihkan pendapatan yang akan digunakan oleh memenuhi kebutuhan hidup.

Berdasarkan variabel modal (X1). Sebanyak 51 orang berpendapat bahwa modal berdagang pedagang Pasar Sentral Palaka Kecamatan Tanete Riattang Timur Kabupaten Bone berasal dari dana sendiri dan gunakan untuk pengadaan sarana dan prasarana lain (alat-alat yang digunakan untuk berdagang). Jadi, setiap kegiatan ekonomi akan dapat menyisihkan pendapatan yang akan digunakan oleh memenuhi kebutuhan hidup Tetapi bukan berarti merupakan faktor satu-satunya yang dapat meningkatkan pendapatan. Sehigga dalam hal ini modal bagi pedagang juga merupakan salah satu faktor produksi yang mempengaruhi tingkat pendapatan pedagang pasar sentral palakka.

Hasil penelitian sejalan dengan hasil penelitian dari penelitian Nur Isni Atun (2016) modal berpengaruh positif terhadap pendapatan pedagang Pasar Prambanan Kabupaten Sleman. modal berpengaruh positif terhadap pendapatan pedagang Pasar Juwana Baru Kabupaten Pati. Penelitian Deasa Nurhausan Albana (2017) modal berpengaruh positif terhadap pendapatan pedagang Kaki Lima Malioboro Pasca Revitalisasi Parkir. 


\section{b. Pengaruh Jam Berdagang Terhadap Pendapatan Pedagang Pasar Sentral Palakka di Kabupaten Bone}

Berdasarkan hasil uji t diperoleh keterangan bahwa Jam Berdagang berpengaruh signifikan $(0.001>0.05)$ menunjukan hubungan positif terhadap pendapatan pedagang. Semakin lama pedagang berjualan maka pendapatan pedagang akan meningkat.

Hal ini berarti sesuai dengan kajian teori dalam penelitian ini. William A. Mc Eachern (2001) mengatakan bahwa pekerja mampu mengendalikan jumlah jam kerja mereka per minggu. Pilihan antara kerja separuh waktu dan kerja penuh waktu memungkinkan para pekerja menggabungkan jumlah jam kerja yang mereka inginkan. Jadi para pedagang Pasar Sentral Palakka Kabupaten Bone tidak terikat dengan jam kerja. Pedagang pasar beranggapan semakin banyak jam kerja yang dilakukan pedagang dalam melakukan perdagangan, semakin besar peluang memperoleh pendapatan yang akan di dapat oleh pedagang.

Jam Kerja adalah waktu untuk melakukan pekerjaan dapat dilaksanakan siang hari dan/atau malam hari. faktor yang penting lain dijalani pedagang dalam menjalankan usaha. Lama usaha adalah lama waktu yang sudah di jalani pedagang dalam menjalanka usahanya. Selain itu, faktor penting dalam mengelolah suatu usaha adalah menentukan jam kerja. Jam kerja adalah banyaknya waktu kerja sehari. Konsumen tidak dapat dipastikan kedatangannya. Sehingga dengn jumlah jam berdagang yang semakin banyak maka pedagang memiliki waktu yang banyak dalam menunggu kedatangan konsumen. Konsumen juga terbantu dengan adanya pedagang yang memiliki porsi jam kerja tinggi untuk berdagang karena kebutuhan yang dicari mampu diperoleh tanpa kesulitan bahkan tidak perlu menunggu hingga keesokan harinya. Namun demikian tidak berarti penambahan jam kerja melebihi jam kerja pasar.

Analisis jam kerja merupakan bagian dari teori ekonomi mikro, khususnya mengenai teori penawaran tenaga kerja yaitu khususnya mengenai kesediaan individu untuk dapat bekerja dengan harapan memperoleh penghasilan atau tidak sama sekali bekerja dengan konsekuensi rela mengorbankan penghasilan yang seharusnya didapatkan. Mengenai jam kerja bagi individu tinggal memilih apakah ingin bekerja dengan jangka waktu yang lama atau jangka waktu yang pendek. Keputusan tergantung dari individu sebab kegiatan dalam bekerja adalah keputusan yang mutlak dari seorang individu. 
Pada sektor informal tidak mengenal yang namanya jam kerja standar, akan tetapi mereka bekerja dengan jam kerja yang tidak terbatas. Yang terpenting bagi mereka adalah penghasilan pendapatan yang lebih tinggi tanpa menghiraukan jam kerjanya. Seperti halnya bagi para pedagang dimana jam kerja bukan suatu tuntutan bagi mereka untuk bekerja namun dalam bekerja mereka bebas memilih jam untuk memulai kerja begitupun berhenti dari pekerjaannya. Jam kerja sangat erat hubungannya dengan tingkat pendapatan seseorang, semakin banyak jam kerja yang dipergunakan maka semakin tinggi pendapatan yang diterimanya.

Untuk jam buka pedagang sendiri sangat bervariasi tergantung jenis komoditas yang diperjual belikan dan lokasi mereka berjualan. Bagi pedagang yang menjual kebutuhan pokok kebanyakan berjualan dari jam 6 pagi, bahkan ada yang lebih pagi. Bagi pedagang baju dan toko-toko biasanya buka antara 8-9 pagi, jam kerja pasar sentral palakka sendiri rata-rata kurang lebih 8 jam. Mulai pukul 05.30 WITA pasar sentral palakka sudah ramai pelanggan dan pukul 11.00 WITA sudah mulai surut. Meskipun demikian, banyak pedagang yang berjualan sampai jam 10 malam bagi penjual kebutuhan pokok. Sehingga guna meningkatkan pendapatan mereka, pedagang bisa langsung memperpanjang waktu jam kerjanya karena tidak ada batasan waktu untuk berdagang di Pasar Sentral Palakka.

Hasil penelitian sejalan dengan hasil penelitian dari Ike Wahyuni Nurfiana (2018) jam kerja berpengaruh positif terhadap pendapatan pedagang pasar. Penelitian Sundari (2017) jam kerja berpengaruh positif terhadap pendapatan pedagang dalam persfektif islam. Penelitian Safatur Rohmah (2017) jam kerja berpengaruh positif terhadap pendapatan pedagang Pasar Juwana Baru Kabupaten Pati. Penelitian Deasa Nurhausan Albana (2017) jam kerja berpengaruh positif terhadap pendapatan pedagang Kaki Lima Malioboro Pasca Revitalisasi Parkir.

\section{Pengaruh Lokasi Terhadap Pendapatan Pedagang Pasar Sentral Palakka di Kabupaten Bone}

Dari hasil uji t diketahui bahwa lokasi berpengaruh signifikan $(0,004<0,05)$ dan berhubungan positif terhadap pendapatan pedagang Pasar Sentral Palakka di Kabupaten Bone. Sebuah pasar yang letaknya strategis akan lebih terjamin kelancaran penjualannya dari pada yang letak tempatnya kurang strategis. Faktor-faktor keramaian lalu lintas, kemungkinan tempat pemberhentian orang untuk berbelanja, keadaan penduduk di lingkungan pasar, keadaan perparkiran dan sebagainya merupakan hal-hal yang perlu diperhatikan dalam penentuan lokasi pasar. 
Pengaruh positif variabel terhadap pendapatan pedagang dalam penelitian ini sesuai dengan pasar Losch, dari Agust Losch dimana lokasi penjual sangat bepengaruh terhadap jumlah konsumen yang dapat digarapnya. Sehingga lokasi berjualan berkaitan erat dengan ketertarikan para pembeli untuk membeli dagangannya dan akan berpengaruh terhadap pendapatan dari pedagang tersebut.

Pedagang pasar adalah sesorang yang mempunyai usaha dan tempat permanen sesuai dengan jenis usahanya dan dalam penampilan barang dagangan mempunyai variasi baik dalam penataan, kemasan, kebersihan sehingga bisa menarik para pembeli atau pelanggannya. Untuk meningkatkan pendapatan pedagang pasar sentral palakka yang jauh dari keramaian, konsumen atau pembeli yang berkunjung adalah pelanggang yang berdatangan karena penataan barang dagangan tertata rapi dan menjaga kebersihan lokasi berdagang.

Pasar membutuhkan lahan dan lokasi yang strategis, mengingat aktivitas yang terjadi di pasar tersebut dan pentingnya peran pasar sebagai salah satu komponen pelayanan kota, daerah dan wilayah yang mengakibatkan kaitan dan pengaruh dari masingmasing unsur penunjang kegiatan perekonomian kota. Dengan letak yang strategis, akan lebih terjamin proses transaksi jual-belinya dari pada pasar yang letaknya kurang strategis. Dalam hal ini harus diperhatikan faktor-faktor keramaian lalu lintas, kemungkinan tempat pemberhentian orang untuk berbelanja, keadaan penduduk di lingkungan pasar, keadaan perparkiran dan sebagainya.

Pengertian pendapatan merupakan unsur yang sangat penting dalam sebuah usaha perdagangan, karena dalam melakukan suatu usaha tentu ingin mengetahui nilai atau jumlah pendapatan yang diperoleh selama melakukan usaha tersebut. Dalam arti ekonomi, pendapatan merupakan balas jasa atas penggunaan faktor-faktor produksi yang dimiliki oleh sektor rumah tangga dan sektor perusahaan yang dapat berupah gaji/upah, sewa, Bunga serta keuntungan/profit .

Berdasarkan hasil penelitian variabel lokasi, Sebanyak 25 orang (30.8\%) berpendapat bahwa lokasi berdagang tidak baik karena lokasi pasar jauh dari pusat kota dan lokasi los berada dipojok pasar. Lokasi usaha yang strategis akan mudah dilihat oleh konsumen, sehingga akan banyak konsumen datang berbelanja. Meningkatnya jumlah pelanggan berakibat pada peningkatan laba bersih usaha. Jarak dengan pemukiman 
masyarakat yang diperkirakan akan berkunjung sebaiknya juga tidak terlalu jauh, dan untuk mencapainya tersedia cukup fasilitas transportasi atas aksesibilitas yang lancar. Hal ini menjadikan lokasi pasar yang jauh dirasakan menjadi lebih dekat yaitu adanya jalan dan alat transportasi, kemudahan parkir, kelengkapan dan kualitas barang-barang yang dijual dan kemudahan untuk mencapai lokasi.

Penerapan konsep lokasi perusahaan sebagai produsen atau pihak yang menghasilkan barang terhadap produsen di lokasi pasar memiliki beberapa hal yang cenderung identik. Pada prinsipnya produsen akan memilih lokasi produksi yang dekat dengan pasar, terutama dalam menghemat biaya transportasi. Tingginya biaya transportasi dalam pengangkutan hasil produksi akan menyebabkan harga barang juga semakin tinggi. Lain halnya jika pasar yang dimasuki adalah persaingan sempurna, dimana diskriminasi harga tidak berlaku dan barang yang ditawarkan adalah identik sama dengan produsen lain. Dengan demikian, semakin tinggi biaya transportasi, maka keuntungan bagi produsen dari hasil penjualan akan lebih kecil dibandingkan bila biaya transportasi bisa ditekan dengan memperkecil jarak dari lokasi produsen atau perusahaan ke lokasi pasar.

Bahwa kondisi stabil dan diinginkan adalah kondisi keseimbangan (equilibrium) yang dapat memuaskan pihak yang berkepentingan, yaitu produsen dan konsumen. Kondisi keseimbangan ini dapat berbeda baik dari sudut pandang pedagang atau pengusaha atau dari sudut pandang masyarakat umum. Hasil penelitian sejalan dengan hasil penelitian dari Ike Wahyuni Nurfiana (2018) Lokasi berpengaruh positif terhadap pendapatan pedagang pasar. Penelitian Sundari (2017) lokasi berpengaruh positif terhadap pendapatan pedagang dalam persfektif islam. Penelitian Deasa Nurhausan Albana (2017) lokasi berpengaruh positif terhadap pendapatan pedagang Kaki Lima Malioboro Pasca Revitalisasi Parkir.

\section{KESIMPULAN / CONCLUSION}

Berdasarkan hasil penelitian dari hasil data dilapangan dapat disimpulkan bahwa pengaruh variabel modal terhadap tingkat pendapatan pedagang adalah positif. Hal ini dapat dilihat dari nilai koefisien regresi variabel modal sebesar 0,733. Artinya bahwa modal berpengaruh terhadap tingkat pendapatan pedagang pasar. Sementara pengaruh jam berdagang terhadap tingkat pendapatan pedagang adalah positif. Hal ini dapat dilihat dari nilai koefisien regresi variabel modal sebesar 523266.071. Artinya bahwa jam berdagang berpengaruh terhadap tingkat pendapatan pedagang pasar. Hasil uji pengaruh lokasi terhadap tingkat pendapatan pedagang menunjukkan pengaruh yang positif. Hal ini dapat dilihat dari nilai koefisien regresi variabel modal sebesar 283397.177. Artinya lokasi 
berpengaruh terhadap tingkat pendapatan pedagang pasar. Koefisien regresi sebesar -4.403 artinya modal (X1), jam berdagang (X2), dan lokasi (X1) kurang dari 100\% maka tingkat pendapatan, tidak mengalami perubahan . Artinya semua variabel modal, jam berdagang, dan lokasi terhadap variabel pendapatan mempunyai pengaruh signifikan.

\section{DAFTAR PUSTAKA / REFERENCES}

Badan Pusat Statisik Provinsi Sulawesi Selatan. 2017. Sulawesi Selatan.

Badan Pusat Statisik Provinsi Sulawesi Selatan. 2018. Sulawesi Selatan.

Chen, H.M and Lin, K.J. 2003. The Measurement of Human Capital and Its Effect On The

Analysis of Financial Statements. International Journal of Management, Vol. 20, No.4

Davemport, T.O. 1999. Human Capital: What It Is and Why People Invest In It. Jossey Bass, San Francisco.

Fitz-enz, J, 2000. The ROI of Human Capital: Measuring the Economic Value Added of Employee Performance. AMA-COM, American Management Association, New York https://rizafirman.wordpress.com. Diakses: 29 Januari 2018.

Mankiw, N.Gregory. 2007. Makroekonomi, Ed.6. Jakarta: Erlangga

Schultz, Theodore, W. 1961. Investment in Human Capital . The American Economics Review.

Paul Michael Todaro. 2003. Pembangunan Ekonomi Di Dunia Ketiga. Jakarta.

Swastha, Basu. 2012. Manjemen Penjualan. Yogyakarta: BPFE-Yogyakarta.

Nur Isni Atun. 2016. Pengaruh Modal Terhadap Pendapatan Pedagang Pasar Prambanan, Kabupaten Sleman.

Deasa Nurhausan Albana. 2017. Pengaruh Modal Terhadap Pendapatan Pedagang Kaki Lima Malioboro Pasca Revitalisasi Parkir.

Soekartawati. 2002. Faktor-faktor Produksi. Jakarta: Salemba Empat. 